\title{
The rivers of Scotland: The Beauly and Conon
}

\author{
Lionel W. Hinxman B.A., F.R.S.E.
}

To cite this article: Lionel W. Hinxman B.A., F.R.S.E. (1907) The rivers of Scotland: The Beauly and Conon, Scottish Geographical Magazine, 23:4, 192-202, DOI: 10.1080/00369220708733740

To link to this article: http://dx.doi.org/10.1080/00369220708733740

册Published online: 27 Feb 2008.

Submit your article to this journal 저

Џll Article views: 10

Q View related articles $\sqsubset$

Citing articles: 1 View citing articles $\square$ 


\title{
THE RIVERS OF SCOTLAND: THE BEAULY AND CONON.
}

\author{
By Lionel W. Hinxuan, B.A., F.R.S.E.
}

\section{(With Map and Diagrams.)}

UNLIKE the Spey and other large streams of the north-east coast south of the Moray Firth-rivers of simple type in which the tributaries are throughout distinctly subordinate to the main stream-the Beauly and the Conon are examples of a complex river system, formed of several large streams nearly equal in length and volume, and confluent at a comparatively short distance above the river mouth.

This character is most marked in the case of the Beauly, and is indeed apparent in the nomenclature of the river system. The Affric, the Cannich, and the Farrar, streams of almost equal volume, unite to form the river Glass, which at some indeterminate point in its course between Struy and Eilean Aigas ceases to bear that name and flows to the sea as the Beauly River. ${ }^{1}$

The apparent redundancy in the name Glen Strath Farrar now given to the valley of the Farrar, may possibly be accounted for when we remember that the Beauly Firth was the REstuarium Vararum of the early geographers, the estuary of the Varar-that name being evidently applied to the whole of the Farrar-Beauly river. The lower and wider portion of the valley would then be the Strath-the upper section, above Struy, the Glen-of the Farrar. When in later times the name Farrar ceased to be given to the river below Struy, and that portion of the valley became merged in Strath Glass, the name Glen Strath Farrar remained to indicate the "glen" portion of the vanished Strath Farrar.

\section{The Beauly.}

The Beauly river system falls naturally into four well-defined sections.

1. The mountain valley section. This includes the torrent heads, the lake basins, and the lower courses of the Affric, the Cannich, and the Farrar. The last two of these flow in a direction transverse to the general "graining" of the country, while the trend of the Affric is transverse-oblique.

2. The flat valley track, represented by the course of the river Glass, longitudinal between Fasnakyle and Erchless, and transverse from Erchless to Eilean Aigas.

3. The gorges of Eilean Aigas, the Druim, and Kilmorack.

4. The lower course of the Beauly, between the foot of the gorges and the sea.

It is unnecessary to trace in detail the courses of each of these streams, as they can be followed on the map. Some figures, however, may be

1 The whole stream below the mouth of the Farrar is often called the river Beauly; but, on the other hand, Strath Glass is generally considered to extend to the head of the gorge at Eilean Aigas. 


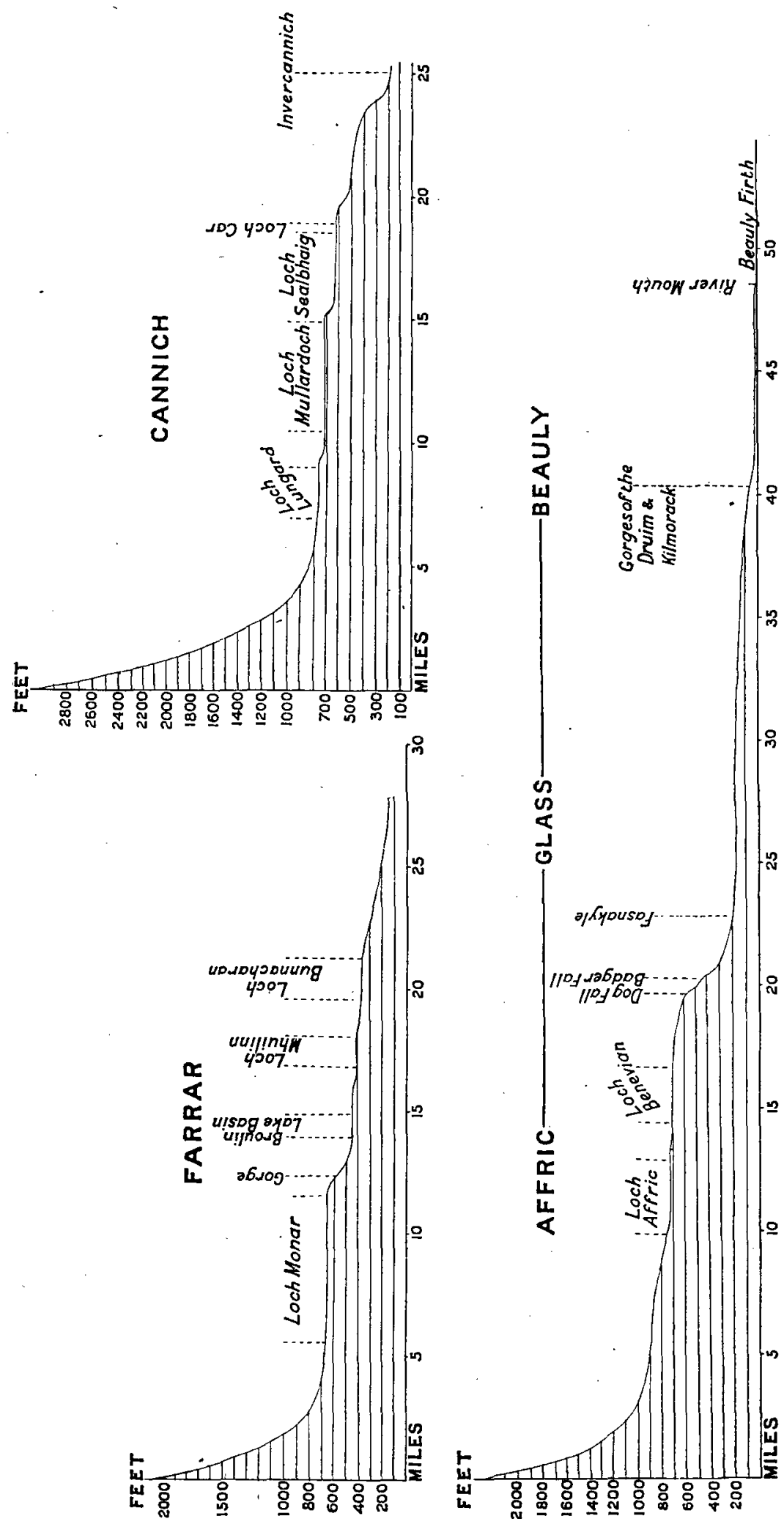


useful in order to give an idea of the relative proportions of the different sections of the river system. The area of the entire basin is approximately 407 square miles, the greater part of which is high mountain ground. The watershed lies within a few miles of the western seaboard, the sources of the Affric, Cannich, and Farrar being distant respectively $5,7 \frac{1}{4}$, and $7 \frac{1}{2}$ miles from the salt water of Lochs Duich and Carron. The lengths of the component streams, measured along the principal. windings, and including the lochs through which they pass, are as follows. The Affric to Fasnakyle, 21 miles; the Cannich, 24 miles; the Farrar, 28 miles; the Glass from Fasnakyle to Eilean Aigas, 16 miles; the Beauly from Eilean Aigas to Tarradale, $10 \frac{1}{2}$ miles. The total length of the Affric-Glass-Beauly is therefore $47 \frac{1}{2}$ miles, of the CannichGlass-Beauly 48, and of the Farrar-Glass-Beauly $44 \frac{1}{2}$ miles.

Section 1.-Resembling one another in the physiographical character of their basins, and in the causes which have controlled the evolution of their valleys, the Affric, Cannich, and Farrar differ only in the extent to which each has graded its course. They are essentially immature rivers; that is to say the fall from source to mouth is unequally distributed over their course, so that the profiles, shown in the accompanying diagram, depart largely from the smooth curve of a perfectly graded stream.

Each of these rivers presents a succession of lake basins, or stretches in which the local base-level of erosion has been approximately reached, succeeded by rock barriers which usually correspond to constrictions of the valley, and are in most cases due to hard and less easily eroded bands of rock.

The grading process has reached the furthest stage in the Farrar. The rock barriers along the course of that river have been to a considerable extent cut through, so that gorges and rapids, rather than waterfalls, mark the successive steps in the fall of the valley. A further effect of this partial lowering of the barriers is seen in the draining of former lakes, such as that represented by the wide alluvial flat below Broulin Lodge; and the lowering of the waters of the existing lochs indicated by the terraces which surround Loch Mhuilinn and Loch Bunacharan, and mark the former level of their waters. In Glen Cannich we find an earlier stage of valley grading. Here the chain of lochs is strung so closely on the river thread that of the 18 miles of its course-neglecting the torrent head-nearly 8 miles are through lochs, and the connecting links of river, between Loch Lungard and Loch na Cloiche, Loch Mullardoch and Loch Sealbhag, only a few hundred yards in length. The erosion of the successive rock barriers is less advanced than on the Farrar, and the waters of almost all the higher lochs escape either over a fall or down a steep rapid little less than a fall. Only in the lower part of the glen has the river cut back sufficiently to produce a gorge such as that below Loch Craskie, and lower to some extent the waters of the loch above. The higher lochs show no signs of shrinkage, but terraces marking a slightly higher level are found round Lochs Sealbhag, Car, and Craskie.

The profile of the Affric is of a still simpler character. The 
total fall of the river to Fasnakyle is 2530 feet, of which 1850 feet takes place along the five-mile course of the mountain torrent above Alltbeath. The remaining fall of 680 feet is very unequally distributed over a course of 19 miles. Nine miles of this distance, from the head of the silted-up portion of Loch Affric to Achagate below Loch Beinn a' Mheadhoin, is practically a lake basin, with a fall only of 40 feet in the short length of stream above Loch na Laghan; and of the remaining 480 feet the river drops 310 feet in the $1 \frac{1}{2}$ miles which include the Dog Falls, the Badger Falls, and the connecting rapids. This sudden drop in level is represented on the profile diagrams by the steepening of the curve between the 20th and 25th mile, a feature which is most strongly marked on the Affric, less so on the Cannich, and is comparatively smoothed on the Farrar. This sudden steepening of the gradient corresponds more or less closely in each valley with the outcrop of a belt of gneissose rocks, much folded and resting at high angles. It may, therefore, be due to the superior resisting power of these rocks compared with those at the mouth of the valleys, while it is possible that the latter may have been more or less shattered by a line of fracture which passes along Strath Glass, and thus rendered more subject to erosion.

An over-deepening of the upper part of Strath Glass with regard to the tributary valleys might also be suggested as a cause of the sudden drop at the foot of Glen Affric, which might thus be regarded as a hanging valley. It is, however, difficult to suppose that a volume of ice passed into the head of Strath Glass larger than that which must have descended from the wide extent of lofty mountain ground that surrounds the upper portions of Glen Affric and Glen Cannich.

Before passing to the next section, some interesting points in the earlier history of the Farrar may be referred to.

Of the two streams which fall into the head of Loch Monar, the Amhainn an-t-Sratha Mhoir or Strathmore river has now the greater volume, and may be regarded as the real head of the river Farrar. The other, the Allt Loch Calavie, flows for the greater part of its course through a chain of lochs lying in a wide level valley, which heads up to the main watershed of the country at a point where it is only 865 feet above sea-level. The low drift-covered col rises but a few feet above the stream on the western side of the watershed, a tributary of the river Ling, and the flat marshy valley of the Allt an. Loinfhiodha as far down as the foot of Loch Cruoshie is clearly a continuation of the hollow by which the eastern drainage now passes through the Gead Lochs into Loch Monar. The stream below Loch Cruoshie is rapidly eroding its present steep gorge, and it is evident that since glacial times it has cut back eastwards sufficiently to rob the headwaters of the Farrar of the volume represented by the three burns which now flow into Loch Cruoshie.

The gorge of the Garbh Uisge below Monar Lodge is a recent postglacial portion of the river channel. Its earlier course, occupied at a time when the valley south of Beinn na Muice was probably blocked with ice, lay through the hollow between Loch Bad na h'Achlaise and the 
Uisge Misgeach. Other higher channels occupied by the river during former stages of the grading of its course can be detected immediately above Ardchuilk, at the level of the road between Lochs Mhuilinn and Bunacharan, and again at the roadside half a mile below Deannie Lodge.

The bathymetry of Loch Monar and of most of the other lochs mentioned in this paper has been fully discussed in the Reports of the Scottish Lake Survey published from time to time in the pages of this Magazine. ${ }^{1}$ It will therefore be sufficient to say that all or nearly all these lochs occupy rock-basins, though, in some instances, their waters are partially held up by drift or alluvial deposits. Ice has in every case been the principal eroding agent, and the powerful fanlt which crosses Loch Monar in an oblique direction has probably played an important part, as a line of weakness, in the evolution of that loch. The smaller lochs are all of comparatively recent origin, and may be regarded as only transient features, that under present conditions are being slowly obliterated by the grading of the river valleys.

Section 2.-Between Fasnakyle and Erchless the river Glass occupies a straight, trench-like, longitudinal valley, whose trend has been determined by a line of fault. The fall of the valley floor from Invercannich to Struy, a distance of $6 \frac{1}{2}$ miles, is only 15 feet; the stream has graded its course, and now winds in sluggish curves, with here and there an "oxbow" lake representing a former "cut-off," through a deep deposit of silt, sand, and fine gravel.

There is little doubt that this portion of the valley is a waste-filled basin, at one time occupied by a narrow glen-lake comparable on a small scale with Loch Ness, and like it, developed along a NNE.-SSW. line of fracture and consequent weakness. The waters of this lake probably extended to the head of the gorge at Eilean Aigas and were gradually drained by the erosion of the rock barrier below, while the higher reaches were being silted up with the material brought down by the mountain streams.

At Eilean Aigas the character of the river completely changes. The wide haughlands and sweeping curves of the Glass give place to the picturesque gorges through which the Beauly rushes in alternating fall and rapid amid the beautiful scenery of the Druim and Kilmorack. These gorges have been cut deep into the Old Red Sandstone conglomerate, and in places even reach the underlying floor of metamorphic rock.

A feature common to most of the rivers that fall into the Moray Firth is the abnormal steepening of the lower part of their course, generally at or near the point where they breach the inner or landward margin of the Old Red Sandstone belt.

In a former paper on the Spey ${ }^{2} I$ have attributed this phenomenon, which is particularly well marked in the case of that river, to the rejuvenation produced by an uplift later than the deposition of the Old Red Sandstone. In the case of the Beauly it seems probable that the more recent uplift which raised the shore-line 100 feet above its present

1 Vol. xxii. No. 9, 1906 ; vol. xxi., 1905.

2 "The River Spey,"Scottish Geographical Magazine, April 1901. 
level was an important factor in the production of the lower gorges. The 100-feet beach, which forms a conspicuous feature along the shores of the Beauly Firth, can be traced to the mouth of the Kilmorack gorge, while the 100-feet contour-line crosses the river at Teanassie, more than a mile higher up. It is evident that erosion must have been largely accelerated on the down-stream side of the uplift by the steepening of the gradient.

At the mouth of the Kilmorack gorge the Beauly enters the final section of its course, and flows gently over a wide alluvial plain to the sea: Above the village of Beauly the river is eroding the marine deposits of the successive raised beaches, while below it pushes out into the head of the Beauly Firth an ever-advancing delta of silt and mud, closely similar to the estuarine shelly clays that extend far up the valley of the Conon to the limit of the 100 -foot beach.

The course of the Beauly between Eilean Aigas and the sea is entirely postglacial. An earlier preglacial channel is indicated by the hollow of Lonbuie, which runs from Eskadale through Fanellan to Beaufort Castle. The higher part of this hollow is now deeply filled with boulder clay, the lower portion with alluvial sand and gravel. From Beaufort the river probably flowed through the low-lying tract of ground occupied by the now drained Moniack Moss to the sea between Clunes and Lentran. ${ }^{1}$

Having thus discussed in more or less detail the courses of the streams that form the present Beauly river system, it remains to consider briefly the earlier history of its development.

It seems probable that the Farrar, Cannich, and Affric represent the headwaters of a consequent easterly-flowing river system developed on the original surface of the Old Red Sandstone plateau, which we know from the outlying fragments of that formation found far up the inland valleys, must at one time have covered the eastern side of the watershed up to a height of at least 2500 feet above present sea-level.

A study of the map shows the significant manner in which the wide valley of Glen Urquhart and Corrimony heads up to a well-marked depression in the eastern wall of Strath Glass, directly opposite to the mouth of Glen Cannich, and continues the line of that glen eastwards to Loch Ness. It is therefore not unreasonable to suppose that Glen Urquhart once formed part of the course of a large eastward-flowing river, whose head-waters were captured by a longitudinal stream at the time when the removal of the Old Red Sandstone covering by denudation brought into play the features of an earlier drainage system, and diverted the confluent waters of the Cannich and the Affric into the pre-Old-Red-Sandstone valley of Strath Glass.

The Farrar-Glass-Beauly still preserves more or less its easterly course, but the lower part of the valley has been largely modified by subsequent events, and in earlier times the river probably flowed over a plain of Old Red Sandstone that occupied the position of the Beauly Firth, discharging its waters into the Moray Firth far to the eastward of the present shores of the Black Isle.

1 As suggested by Mr. Wallace in his article "Geological Changes in the Moray Firth." Trans. Inverness Scientific Soc.; vol. ii. p. 384. 


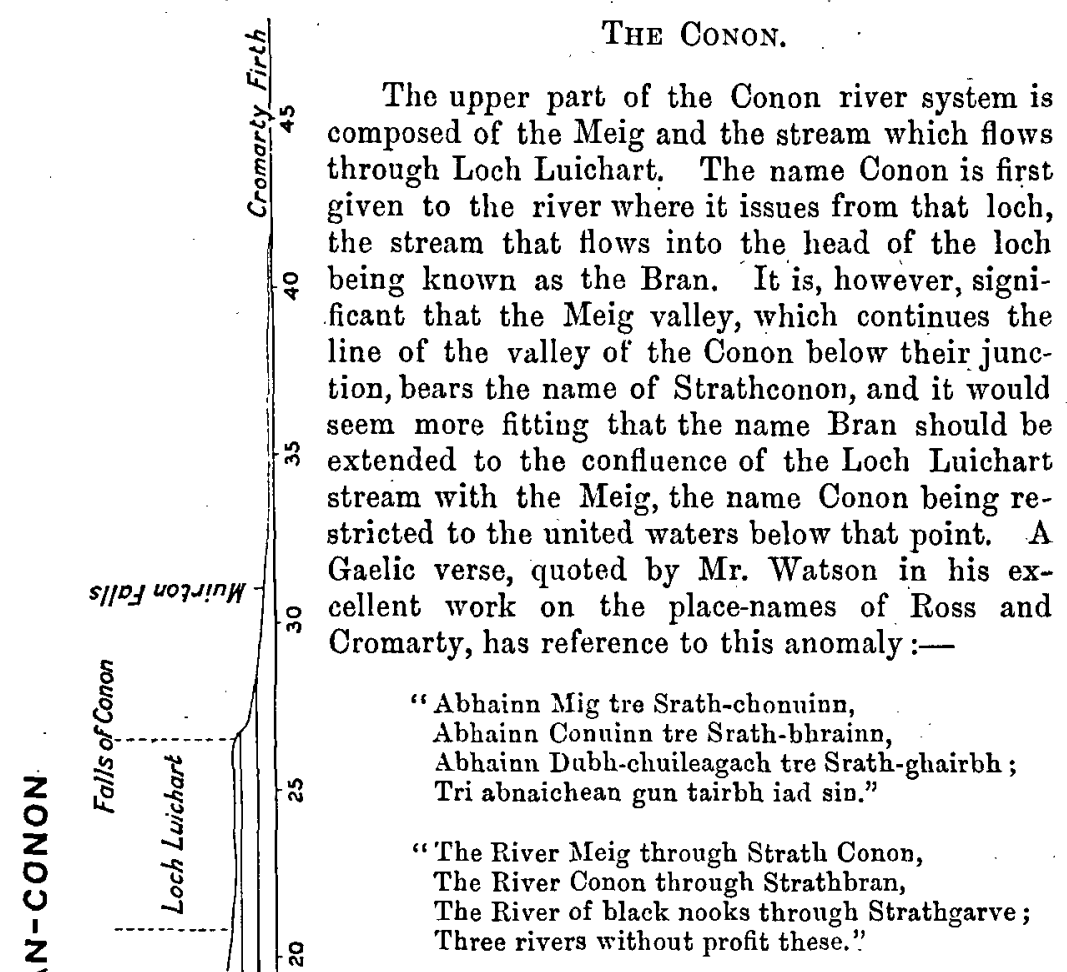

At Contin (the confluence) the river is joined by its most important tributary, the Blackwater, and four miles above its mouth receives on the right bank the waters of the Orrin. The area of the Conon drainage basin approximates to 483 square miles. The lengths of the various sections are as follows: the Meig, $24 \frac{1}{2}$ miles; the Bran, to the foot of the Meig, $26 \frac{1}{2}$ miles; the Bran- Conon, $38 \frac{1}{2}$ miles; and the Meig-Conon, $36 \frac{1}{2}$ miles. The principal tributaries of the lower river, the Blackwater and Orrin, measure respectively 28 and 23 miles in length.

The mountain torrent which forms the headwaters of the Bran-Conon rises at a height of 1500 feet on the slopes of Carn Breac, at a point only 9 miles distant from the salt water of Loch Torridon, and falls 1000 feet in its course of 5 miles to the head of Loch a' Chroisg (Rosque). Issuing from the loch as the river Bran, the stream

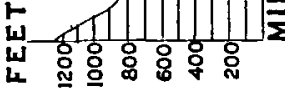
is cutting through the high-level terraces of sand and gravel which are seen on either side of the railway a short distance to the west of Achnasheen station. These represent, as pointed out by Dr. Penck of Vienna, 
and further described by Dr. B. N. Peach, delta deposits laid down in an ancient lake, which was held up by masses of ice lying in the valley to the east and south of the present junction of the Bran with the stream flowing out of Loch Gown.

From Achnasheen the river winds eastwards with a gentle fall through the grassy alluvial stretches of Strathbran, its straighter course immediately above Dosmuckeran indicating a steeper gradient where the stream leaves the floodplain and has cut a shallow gorge through the flagstones at the foot of Druim Dubh. Below Dosmuckeran the river meanders in sluggish curves between high banks of sand and clay through a flat stretch of meadow land. This alluvial flat is the silted-up head of a large loch, now represented only by the shallow reedy waters of Loch Achanalt and Loch Cuilinn. In addition to the filling up of this earlier lake by the stream at its head, its waters were lowered by the cutting back of the rock barrier below Loch Cuilinn, and the latter loch separated from Loch Achanalt, the former connection of the two lakes being plainly indicated by the continuous terraces that can be traced around them both. After leaving Loch Cuilinn the Bran passes in rapids and small waterfalls over a series of rock barriers, above each of which the stream expands into a wide reach of comparatively still water, and falls 110 feet to Loch Luichart in a distance a little less than two miles. A mile above that loch it is joined by the Grudie river, which drains Loch Fannich and the southern slopes of the Fannich mountains. This is a rapid rocky stream, and falls 460 feet in the last $3 \frac{1}{2}$ miles of its short course from the loch. The bathymetry of Loch Luichart presents some interesting features, which are fully discussed in the Report of the Scottish Lake Survey on the lakes of the Conon basin. ${ }^{1}$ It may, however, be pointed out that the abnormal depth found close to the head of the loch is probably due in great measure to the powerful wrench-fault which here crosses the lake. The effect of this line of movement would be to shatter and disintegrate the rock and thus increase the erosive effect of the moving ice at this point.

The most prominent feature in the profile of the Bran-Conon, below Loch a' Chroisg, is the sudden drop below Loch Luichart, where, in a distance of just under a mile, the river falls 130 feet between the rocklip of the loch at the Falls of Conon and the mouth of the gorge at Little Scatwell. It is noticeable that the Falls of Conon occupy an almost exactly similar position with regard to the loch above and gorge below as do the Rogie Falls on the Blackwater river, referred to in the sequel. The erosion of the Loch Luichart barrier has, however, not yet been sufficient to lower appreciably the waters of the loch above and produce a marginal terrace as is the case with Loch Garve.

The course of the Meig is less varied than that of its sister stream the Bran. Rising at a height of 1200 feet at the head of Gleann Fhiodhaig, it runs with a fairly even fall of. 730 feet in 9 miles to Scardroy at the head of Loch Beannachan. Here a partially eroded barrier of Lewisian gneiss crosses the stream and forms a waterfall,

1 "Lochs of the Conon Basin," Scottish Geographical Magazine, vol: xxi. p. 467, 1905. 
while openings in the barrier at higher levels with corresponding terraces mark former courses of the stream.

The waters of Loch Beannachan lie in a hollow due to erosion along a line of fault that can be traced westwards to Loch Maree.

The Meig issues from Loch Beannachan through a deep accumulation of fluvio-glacial sand and gravel, which to some extent holds up the waters of the loch; and rock is first met with in the bed of the stream a mile below the outlet. Between Inbhirchorainn and Milltown of Strathconon the river runs NNE. and nearly at right angles to its higher course through a straight cañon-like valley, whose lofty and precipitous eastern wall of shattered and reddened rock forms one of the most striking features in the scenery of Strathconon. This valley has been determined by a powerful line of dislocation which can be traced for a great distance through the counties of Ross and western Inverness, with a trend parallel to that of the faults which have determined the Great Glen and the upper part of Strath Glass. This Strathconon fault has already been mentioned as crossing the head of Loch Luichart. At Milltown the Meig leaves the fault-valley and resumes its normal easterly course with a fairly even fall through Strathconon. For a distance of half a mile above Little Scatwell the gradient is less matured, and the stream struggles in a deep and narrow gorge through the siliceous flagstones of Torr a Bhealaich.

Issuing from their respective gorges at Little Scatwell, the Meig and Bran enter a wide flood-plain, through which their waters, united in the Conon river, flow to a point below Comrie where the valley is again constricted, and a band of siliceous rock crossing the stream has produced a low waterfall and rock gorge below.

The next steep drop in the gradient is found at the Muirton Falls just above Newton, where the Conon encounters the coarse breccia of Old Red Sandstone age which forms Torr Achilty. The fall or steep rapid caused by the outcrop of this hard conglomerate is succeeded by a stretch of a mile in which the river flows swiftly over a floor of gently inclined grey shales and flagstones. These rocks are on the same horizon as the beds from which are derived the mineral waters of Strathpeffer, and several sulphureous springs rise from the river bed near Clachuile Inn, but are only exposed when the water is at a low summer level.

The insignificance of the Muirton gorge as compared with that cut by the Beauly river through the Old Red Sandstone at Kilmorack is remarkable, but may be explained by the fact that a fault here crosses the river, bringing the shales and flagstones into contact with the lowest portion of the basal conglomerate. The Conon has therefore had an easier task in eroding its channel through these softer rocks than the Beauly on its three-mile course through the hard conglomerates of Kilmorack and the Druim.

It may be pointed out that here again the limit of the 100 -feet raised beach coincides very nearly with the head of the gorge at Tour Achilty. Near Muirton Mains finely laminated blue shelly clays of estuarine character are found up to the 100-feet level, and upon these 
appear to rest the moraines that mark the last retreat of the valley glacier up Strathconon.

From Torr Achilty to the sea the Conon flows through a wide alluvial plain, eroding the marine deposits of the raised beaches, and at the same time laying down its own load of material. At Moy Bridge it receives the waters of the Blackwater, and a short digression must now be made to describe the salient points in the course of this important tributary.

There are many points in similarity between the physiography of the Blackwater and that of the Conon, and these have been determined by closely similar causes. The three large streams which form the headwaters of the river under consideration-the Glascarnoch and the streams which flow through Strath Vaich and Strath Rannoch-each present in some part of its course the usual alternation of lake or drained and silted-up lake-basin with rock gorge through which the stream is eroding the determining barrier below.

Two mountain torrents, draining the southern slopes of Beinn Dearg and the northern corries of the Fannich range, unite a short distance east of the low flat watershed to form the Glascarnoch river. It is, however, evident that the waters of Loch Droma and the Allt a' Mhadaidh, which now flow westwards to Loch Broom, have been stolen from the Blackwater basin by the river Broom, which has cut back more rapidly than the gently graded upper portion of the Glascarnoch stream. The flat alluvial stretch, some four miles in length, above Aultguish Inn is evidently the bed of a glen lake filled up with the detritus brought down by the hill streams, and drained by the erosion of a barrier mainly formed by the belt of foliated granite which crosses the valley above Inchbae.

Below Strath Vaich the valley gradient steepens, and the river falls 430 feet in seven miles to Gortin, at the head of the alluvial fiat which represents the silted-up head of Loch Garve. This loch has also been drained to a considerable extent by the lowering of the rock barrier at the Falls of Rogie, and the conspicuous terraces round the southern part of the loch show the former extent of its waters.

A high terrace of sand and gravel extends from the mouth of the rock gorge eroded by the river below the Rogie Falls to the entrance of the hollow occupied by Loch Achilty, whose waters are to a large extent held up by deep alluvial deposits. There are indications that at an earlier period, when the lower part of the valley was possibly blocked with ice, the water may have passed through this hollow, which connects the valleys of the Blackwater and the Conon.

Two miles below the confluence of these rivers the waters of the Orrin pour in from the south, over a delta of coarse alluvial deposits, through channels that shift with every heavy flood. The course of the Orrin through its wild mountain valley presents no features of special interest. The fall of the stream, 1200 feet, is fairly evenly distributed over its course of 23 miles, but is on the whole greater in the portion below Camban. Loch na Caoidhe, at the head of the valley, occupies a rock basin, and the graded stretch that extends for a mile and a. half 
below Am Fiar Loch represents the former extent of that piece of water. The Orrin Falls are due to the outcrop of a band of conglomerate, greater in resisting power than the softer shales and flagstones below.

Like the Beauly, the Conon was at an early period of its history developed on the eastward slope of a plateau of Old Red Sandstone and, possibly, Secondary rocks, but does not appear to have been modified to the same extent by the reassertion of earlier surface features, and still preserves to a large extent its original consequent course. It is possible, however, that the southward bend of the Blackwater between Garbad and Garve was determined by the high ground of An Cabar and Little Wyvis, and that the pass between those mountains indicates an earlier eastward line of drainage.

The lower course of the Conon, like that of the Beauly, was continued over the Old Red Sandstone plain far to the eastwards of its present mouth, and, as has been suggested by $\mathrm{Mr}$. Hugh Miller, ${ }^{1}$ the opening between the Sutors of Cromarty may have been eroded by the river as it cut its way down through the softer strata by which the gneiss of the Sutors was deeply covered.

\section{THE BLACK MAN'S MIND.2}

THESE two volumes are clear testimony that the importance of West Africa to the student of ethnology is being recognised. Ultimately both deal with the same subject. They are earnest attempts to discover the first principles of the religion of the West African native. Major Leonard, in a large volume of 560 pages, has given us the result of over ten years' study of the tribes in Southern Nigeria, and Mr. Dennett has been reaching forward to the conclusions he arrives at, during a stay of nearly thirty years on "the Coast." Both volumes are intensely interesting, and what has to be said regarding their form had best be said first. The illustrations in Mr. Dennett's book are on the whole well done, and the signs given on $\mathrm{p}$. 71 open up a subject that requires thorough investigation-that of the sign-writing used by the natives. Unfortunately Mr. Dennett overloads his pages with native terms that are very difficult to remember, and to read his book involves the retention in the mind of a goodly number of Bavili and Bini words. It is well that the proof-reading is nearly perfect and the index very full, though there are one or two omissions. On page 65 we have Mvumvuvu, and this is the form found in the index which contains no reference to pages $107 \cdot 8$, where the term is fully explained, and where it is printed Mvumvumvu. Likawla (p. 82) is printed Likaula (p. 84). Major Leonard's book is

1 Transactions of the Inverness Scientific Society, 1885, vol. iij. p. 133.

2 The Lover Niger and its Tribes. By Arthur Glyn Leonard (Macmillan, 12s. 6d. net), At the Back of the Black Man's Afind: or, Notes on the Kingly Office in West Africa. By . R. E. Dennett (Macmillan; 10s, net). 